Walisongo Law Review (Walrev), Vol 1 No. 2 (2019)

DOI: 10.21580/Walrev/2019.1.2.4803

Copyright (C) 2019 Walisongo Law Review (Walrev)

Walisongo Law Review

\title{
Renewal of Criminal Law Politics Relating to Justice Based On Justice
}

\author{
Adhi Budi Susilo", Jarot Jati Bagus Suseno \\ Afiliasi: Universitas Ngudi Waluyo, Semarang; Universitas Prima \\ Indonesia, Medan \\ Email: adhibudisusilosh@gmail.com; jarotjati21@gmail.com
}

\begin{abstract}
Copyright is a high reality of various values, including economic value, this is because copyright that is born of copyright, taste, and intention is able to color the development of human life through objects born from the copyright process. However, in its development various copyrights were not considered in this country. The rise of piracy on song copyrights for example, is only able to benefit the perpetrators of piracy of song copyright economically. The research method used is a juridical legal research method of analysis with the object of research studies aimed at the laws and regulations relating to copyright and principles applicable legal principles. Substantially, the material changes in Law No. 28 of 2014 is related to the change of type of criminal offense from ordinary offense to complaint offense and in the meantime there are not many creators who can seek justice about it. The results of the research are increasingly unfair with the existence of Clause 112 to Clause 119 of Law Number 28 of 2014 changing copyright offenses to complaint offenses that increasingly marginalize the rights of the
\end{abstract}


creators of copyrighted works in this country. Therefore it is necessary to have a joint discussion related to the political development of criminal law related to copyright offenses.

Hak Cipta adalah suatu realitas yang tinggi akan berbagai nilai, termasuk didalamnya nilai ekonomis, hal ini dikarenakan hak cipta yang lahir dari cipta, rasa, dan karsa mampu mewarnai perkembangan kehidupan umat manusia melalui benda yang lahir dari proses cipta tersebut. Namun dalam perkembangannya berbagai hak cipta tidaklah diperhatikan di negara ini. Maraknya pembajakan akan hak cipta lagu misalnya, hanya mampu menguntungkan bagi oknum pelaku pembajakan hak cipta lagu tersebut secara ekonomis, Metode penelitian yang digunakan adalah metode penelitian hukum yuridis analisis dengan objek kajian penelitian yang ditujukan terhadap peraturan perundang-undangan yang berkaitan dengan hak cipta dan prinsip-prinsip hukum yang berlaku. Secara substansial, materi perubahan dalam UU No. 28 Tahun 2014 adalah yang berkaitan dengan perubahan jenis tindak pidana dari delik biasa menjadi delik aduan serta sementara itu pihak pencipta tidak banyak yang dapat mengupayakan keadilan akan hal itu. Hasil dari penelitian semakin bertambah tidak adil dengan adanya Pasal 112 hingga Pasal 119 Undang-Undang Nomer 28 Tahun 2014 merubah delik hak cipta menjadi delik aduan yang semakin memarjinalkan hak dari pencipta suatu karya cipta di negara ini. Oleh sebab itu perlu adanya pembahasan bersama terkait pembangunan politik hukum pidana terkai delik hakcipta.

Keywords: Copyright; Legal Renewal; Fair Value.

\section{Introduction}

The development of science and technology and global trade, encourage the development of Intellectual Property Rights in Indonesia. Initially, the issue of Intellectual Property Rights is very simple, only involving the demand to master and use absolutely something that has been discovered or created with the ability of his energy or intellectual, then extends to the 
issue of who has the right to be the owner of a work if the raw material comes from another party, and so on (Ari Wibowo, 2015: 54 - 75).

This is reflected in the granting of exclusive rights, granting exclusive rights to Intellectual Property Rights holders based on 3 (three) reasons, namely social reasons, economic reasons and reasons for benefits (Mittelstaedt and Mittelstaedt, 1997: 15) even now it is more complex because it has been entered by various interests, such as economic and political interests.

Intellectual Property Rights above generally can be grouped into two types of rights. First, Copyright which includes copyright and other rights related to copyright. Second, Industrial Property Rights which include Patents, Trademarks and Geographical Indications, Plant Varieties, Industrial Designs, Layout Designs of Integrated Circuits, and Trade Secrets. One form of Intellectual Property Rights that has the broadest scope of protected objects, because it includes science, art and literature (art and literary) as well as computer programs is Copyright. So, copyright infringement in the fields of science, art and literature, in principle, is a criminal act as infringement of property rights of others in general (Mashdurohatun, 2012: 72)

Copyright as a part in the field of Intellectual Property Rights is also affected by the harmonization of law. In practice, harmonization of copyrights that has been changed 4 times. Starting with Law Number 6 of 1982 concerning Copyright as amended by Law Number 7 of 1987, which was later amended by Law Number 12 of 1997. Later amended by Law Number 19 of 2002 concerning Copyright, and finally by Law Number 28 of 2014 concerning Copyright. With the aim of protecting the rights of the creator as well as related rights holders (Haryanto, 2014: 43)

The birth of copyright begins with an idea. The idea arises from creativity if thought, by using intellectual intelligence and emotional intelligence possessed by the creator or inventor specifically (exclusive) which is then manifested in the form of creation or invention. Creation or invention is material property rights (tangible), on top of the material property rights attached to immaterial property rights (intangible) (Saidin, 2015: 25) with that Copyright is defined as a special right for the creators to 
copy or reproduce their own works or give permission to other parties (Susilo, 2018: 4) where at this time a lot of other people's work is recognized to be his own, of course this is very contrary to the rule of law.

In Copyright, rights are divided into two major groups, namely moral rights and economic rights. Then moral rights and economic rights can still be divided into various kinds of rights. In accordance with Clause 5 of Law No. 24 of 2014 concerning Copyrights, moral rights are the rights that are eternally inherent in the creator's self to:

a. Continue to include or not mention his name in the copy in connection with the use of his work for the public;

b. Use his real name or pseudonym;

c. Changing his creation according to propriety in society;

d. Change the title and subtitle of the creation; and

e. Defend their rights in the event of creation distortion, mutilation of the work, modification.

Clause 8 of Law No. 28 of 2014 concerning Copyright, Economic Rights are the exclusive rights of the creator or copyright holder to obtain economic benefits for the creation. There are Clauses 5 and 8 of Law No. 24 of 2014 concerning copyright, can be concluded as follows Economic rights are the rights to obtain economic benefits for a work of creation, while moral rights are rights attached to the creator that cannot be removed even if the work has been transferred to another party unless the creator has inherited or in accordance with statutory provisions after the creator dies (Pemerintah RI, 2014)

Protection of the rights mentioned above is very important to be upheld by law, because in the present along with the development of advanced technology, people have forgotten about the concept of respecting the rights of someone behind a work. One example is downloading a copyrighted work on the internet and reproducing copies for profit, plagiarism of someone else's written work for academic purposes or selling pirated CDs without the permission of the creator or copyright holder (Miryansyah, 2017: 2) this breach of violation is often used by parties who want to reap huge profits in an easy way with little cost, without thinking about the losses 
of other parties, which in this case is the creator or inventor and of course the country too (Miryansyah, 2017: 2). Violations copyright in its essence can also be categorized as a criminal offense that can harm a person the creator or inventor.

This means that the occurrence of a criminal offense in the field of copyright can result in losses for the creator and the holder of the copyright, therefore legal remedies are needed. In clause 120 of Law Number 28 Year 2014 it is explicitly stipulated that all criminal acts stipulated in the Act are complaint offense (Pemerintah RI, 2014). This means that all criminal acts from clause 112 to clause 119 of this Law constitute offense for complaint. As for the renewal of criminal law, it can be seen as a change in offense, which originally was an ordinary offense to a complaint offense as law enforcement in the field of copyright.

The issue to be discussed in this paper is related to how is the law enforcement in the implementation of Law Number 28 of 2014 concerning Copyright in combating criminal acts related to copyright so far. In connection with the analysis to discuss the main problems as outlined, the authors use the juridical legal research method of analysis with the object of research studies aimed at the laws and regulations relating to copyright and applicable legal principles. The data used are secondary data obtained from literature or literature related to the subject matter.

\section{Implementation of the Eradication Criminal Acts against Copyright Based}

Copyright, which is part of intellectual property rights, has become an interesting topic for study. There is no denying that at present many copyright violations occur especially in cyberspace (the internet) with a view to benefit oneself or others. Contexts for self-benefit In accordance with clause 378 of the Criminal Code "anyone with a view to benefiting themselves or others against the law, by using a false name or fake dignity, with deception, or a series of lies, moves other people to hand over something to him, or to give debt or write off receivables. "This has 
indirectly caused economic losses, not only for the creator but also for the country.

Therefore, many creators who feel disadvantaged because of the low commitment of the Government, the protection of a work arises automatically since the work is realized in tangible form and registered with the Directorate General of Intellectual Property Rights. Because of the registration of a work that can be used as initial evidence in court if a dispute arises in the future of the work. According to Agus Sarjono in the Minutes of the Special Committee Meeting on Draft Law on Copyright states that the regulation of copyright is included in the area of civil law, because it involves ownership of rights which use civil law, agreements so that law enforcement is actually more there. If it is made a criminal then there is no benefit to the creator of criminal law enforcement. According to him it is better to be civil, which is to compensate the losses suffered by the creator (Minutes of Special Committee on Copyright Draft Meeting, 2014: 21). Agus Sarjono emphasizes that copyright is a civil law material, but actually copyright infringement is also a criminal offense, in principle the criminal law is ultimum remidium. Ultimum remidium means criminal law is the ultimate weapon or the last tool used to solve a legal problem (Hiariej, 2014: 26-27).

The above example states that copyright infringement is also included in criminal material, because in terms of its editorial is a violation, the perpetrators of the violation have an initial intention that is not good by breaking the law. According to Barda Nawawi Arief quoted by Trisno Raharjo, the determination of an offense as an ordinary offense or complaint offense is a matter of policy, thus there are many factors of consideration and alternatives that must be chosen. So it is not solely related to the nature or prominent private interests, thus private interests are not the only factors that must be considered (Trisno Raharjo, 2006: 77).

In the academic paper also explains that based on practice in society, the imposition of ordinary offenses for acts Crime in the field of Copyright in Law Number 19 Year 2002 Concerning Copyright is deemed inappropriate because the copyright is an exclusive civil right. So ideally the violation of copyright is a complaint offense because the one who is most aware of the falsification of a work is the creator himself (Academic Text on Draft Law on 
Copyright, 2013: 25). Because Indonesia is a member and legally participates in TRIPs, through the ratification of the WTO Agreement with Law Number 7 of 1994 (Purba, 2016: 16). With this, Indonesia is bound by all the provisions of the TRIPs Agreement including the provisions on intellectual property rights which are private rights. The status of private rights becomes relevant if in criminal matters, as in Indonesia, the violation is categorized as a complaint offense (Purba, 2016: 16).

So in clause 120 of Law Number 28 Year 2014 expressly stipulates that all criminal acts stipulated in the Act are offense complaints (Pemerintah RI, 2014). This means that all criminal acts from clause 112 to clause 119 of the Law This law is a complaint offense. According to Ismu Gunaidi and Jonaedi Efendi, ordinary offenses or in the Bareskrim terms are pure criminal, that is, all criminal acts that occur, the process cannot be terminated on grounds that can be understood in offense complaints. (Gunaidi and Efendi, 2014: 59).

So it is not possible for the parties to dismiss the case unless it turns into a complaint offense. The creator can revoke the claim within 3 months after the complaint is made, (Clause 75 of the Criminal Code) and can choose the process of case resolution as to what will be taken. So whether they want ordinary offenses or offenses the police continue to protect and supervise, this task is not obstructed by the establishment of complaint offenses. In addition there is also the Directorate General of Intellectual Property Rights which also has the task of supervision, investigation. If these two institutions are maximal in carrying out their duties, surely the authority of law enforcement exists and remains authoritative in the eyes of all the people. However, the enforcement was returned to the victim's choice.

Basically, the basis for consideration of changing copyright offenses into complaints offenses, it is related to Indonesia is a participating country that has ratified the WTO that applies TRIPs as a source of law in which there is a provision that intellectual property rights are private right. This private right statement becomes relevant to the criminal rule, namely offense of complaint, which according to Achmad Zen Umar Purba, but actually this is not enough, because the determination of offense of complaint is not only based on this consideration, but there are also other basic considerations 
that cause why this offense is what first, those who know about a work are the creators themselves, secondly, it is difficult to find original evidence of a work, thirdly, the police do not know whether there is permission or not for the multiplication or multiplication of a work, fourthly, offense complaints provide an opportunity to solve problems by the method of non-criminal settlement or by way of other dispute resolution, and finally, the offense of the complaint does not cause the creator to incur more costs to pay the costs resulting from the existence of two legal proceedings that run if the copyright remains an ordinary offense. (Ramadhan: 2017)

\section{New Materials and Renewal of Criminal Law}

As explained above, the material for the substitution of a law can only be made if there is a change that has resulted in the systematics and the material of the law change by more than 50\% (fifty percent) 15-17 May 2014 previously in the Copyright Law No. 19 of 2002 not illustrated about the protection of economic rights and moral rights for the creators and related rights holders regarding the use of copyright, related rights are multimedia facilities to respond to developments in information and communication technology, piracy issues, complaint offenses, and so on.

\section{Reform Protection of the Economic Right Creators}

In Copyright Law No. 28 of 2014 referred to in detail the substance of the creator's economic rights, namely rights: Issuance of Creation; Doubling of Creation in all its forms; Translation of Creation; Adaptation, Arrangement, or Transformation of Work; Distribution of Works or copies; Performing Creation; Announcement of Creation; Communication of Creation; and Creation of Creation. Whereas previously in the Copyright Law No. 19 of 2002, the substance of the creator's economic rights was only called: the right to announce and reproduce the work. Clause 9 Paragraph (1) of Law No. 28 of 2014 determines that the creator or copyright holder as referred to in Clause 8 has the economic right to do:

a. Issuance of the work;

b. Doubling of creation in all its forms;

c. Translation of creation; 
d. Adaptation, arrangement or transformation of creation;

e. Distribution of works or copies

f. Performing creations;

g. Announcement of creation

h. Communication of creation, and

i. Rental of creation

Copyright protection in Copyright Law No. 28 of 2014 is carried out with a longer period than the period of protection in Copyright Law No. 19 of 2002, namely during the life of the creator plus 70 years after the author died (Clause 59 Paragraph (1) of the New Copyright Act) and specifically applies to the creation in the form of applied works of art, copyright protection is valid for 25 years since it was first performed announcement (Clause 59 Paragraph (2) of the New Copyright Act).

\section{Criminal Law Reform Act 28 of 2014}

In Clause 120 of Law Number 28 Year 2014 it is stated that "Criminal Acts as referred to in this Law is a complaint offense. The criminal acts included in Act Number 28 of 2014 are as referred to in:

a. Clause 112:

Any person without the right to do as referred to in clause 7 paragraph (3), removes, changes and destroys management information and copyright electronic information owned by the copyright holder, and/or clause 52, namely to eliminate, destroy, destroy, or make no it functions as a means of control that is used as a protector of the work and as a security of the work, for commercial use, shall be sentenced to a maximum of 2 years imprisonment and/or a maximum fine of Rp.300,000,000.00. The violation of this clause is according to clause 78 of the Indonesian Criminal Code after 6 years. For those not yet 18 years old, the expiry date, which is a 6 year grace period, is reduced to one third.

b. Clause 113:

1. Every person who without right violates economic rights as referred to in clause 9 paragraph (1) letter i for Commercial Use 
shall be sentenced to a maximum of 1 (one) year imprisonment and / or a maximum fine of Rp 100,000,000 ( one hundred million rupiah). In Clause 9 letter $\mathrm{i}$ the copyright holder or creator has the economic right to lease the work. The violation of this clause is according to clause 78 of the Indonesian Criminal Code after 6 years. For those not yet 18 years old, the expiry date, which is a 6 year grace period, is reduced to one third;

2. Every person who without rights and/or without author's permission or Copyright holder violates the economic rights of the creator as referred to in clause 9 paragraph (1) letter c, letter $\mathrm{d}$, letter $\mathrm{f}$, and / or letter $\mathrm{h}$ for Use Commercials are sentenced to a maximum imprisonment of 3 (three) years and/or a maximum fine of Rp.500,000,000.00 (five hundred million rupiah). In Clause 9 paragraph (1) letter c, namely the right of the creator or copyright holder to translate the work, letter $\mathrm{d}$ is the right to adapt, arrange or transform the work, and letter $\mathrm{f}$, regulates the right of the creator or copyright holder to perform a performance ciptan. The breach of this clause is in accordance with clause 78 of the Indonesian Criminal Code after 1 year. For those not yet 18 years old, the expiry date, which is a 6 year grace period, is reduced to one third;

3. Every person who without rights and/or without author's permission or Copyright holder violates the economic rights of the creator as referred to in clause 9 paragraph (1) letter a, letter $\mathrm{b}$, letter e, and/or letter $\mathrm{g}$ for Use Commercially liable to a maximum of 4 (four) years imprisonment and / or a maximum fine of $\mathrm{Rp}$ 1,000,000,000.00 (one billion). In Clause 9 paragraph (1) letter a, which regulates the rights of the creator or copyright holder to publish the work, letter $b$, regulates the rights of the creator or copyright holder to make copies of the work in all its forms, letter e, regulates the rights of the creator or the copyright holder to distribute the copy or copy, and letter $\mathrm{g}$, which regulates the rights of the creator or the copyright 
holder to make the announcement of the work. The violation of this clause is according to clause 78 of the Indonesian Criminal Code after 12 years. For those not yet 18 years old, the expiry date, which is a 12-year grace period, is reduced to one third;

4. Every person who fulfills the elements referred to in paragraph (3) committed in the form of piracy, shall be sentenced to a maximum imprisonment of 10 (ten) years and / or a maximum fine of Rp.4,000,000,000.00 (four billion rupiahs) ). The violation of this clause is according to clause 78 of the Indonesian Criminal Code after 12 years. For those not yet 18 years old, the expiry date, which is a 12-year grace period, is reduced to one third.

c. Clause 114:

Every person who manages a trading place in all its forms intentionally and knows, allows the sale and/or duplication of goods resulting from violations of copyright and/or related rights at the trade place under his management as referred to in clause 10 , shall be liable to a maximum fine of Rp. 100,000,000 (one hundred million). The violation of this clause is according to clause 78 of the Indonesian Criminal Code after 6 years.

d. Clause 115:

Any person who without the consent of the person portrayed or his heirs uses Commercial Use, Duplication, Announcement, Distribution, or Communication of Portraits as referred to in clause 12 for the purposes of advertising or advertising for Commercial Use in both electronic and non-electronic media, shall be subject to with a maximum fine of Rp.500,000,000.00 (five hundred million). The violation of this clause is according to clause 78 of the Indonesian Criminal Code after 6 years.

e. Clause 116:

1. Every person who without right violates economic rights as referred to in Clause 23 paragraph (2) letter e for Commercial Use shall be sentenced to a maximum of 1 (one) year 
imprisonment and/or a maximum fine of $\mathrm{Rp} 100,000,000$ (one hundred million). Clause 23 paragraph (2) letter e regulates the economic rights of performers which include the right to carry out, give permission, or forbid other parties to lease fixation of shows or copies to the public. The expiration of violation of this clause according to clause 78 of the Criminal Code is after 6 years;

2. Every person who without right violates economic rights as referred to in Clause 23 paragraph (2) letter a, letter b, and/or letter $\mathrm{f}$, for Commercial Use shall be liable to a maximum imprisonment of 3 (three) years and/or a maximum fine of Rp.500,000,000.00 (five hundred million rupiah). Clause 23 paragraph (2) letter $a$, letter $b$, and letter $f$, which regulates the economic rights of performers which include the right to carry out, give permission, or prohibit other parties from broadcasting or communicating on the performance of performers, performing fixation of performances has not been fixed, and made provision for performance fixation that is publicly accessible. The violation of this clause is according to clause 78 of the Indonesian Criminal Code after 6 years;

3. Every person who without right violates economic rights as referred to in Clause 23 paragraph (2) letter c, and/or letter $\mathrm{d}$ for Commercial Use shall be sentenced to a maximum of 4 (four) years imprisonment and / or a criminal fine a maximum of $\mathrm{Rp}$ 1,000,000,000.00 (one billion). Clause 23 paragraph (2) letters $\mathrm{c}$ and $\mathrm{d}$, namely regulating the economic rights of performers which includes the right to carry out, give permission, or prohibit other parties from doubling the fixation of their performances by any means or form, and distributing fixation or copies. The violation of this clause is according to clause 78 of the Indonesian Criminal Code after 12 years.

f. Clause 117:

1. Every person who intentionally and without rights violates economic rights as referred to in Clause 24 paragraph (2) letter c 
for Commercial Use shall be liable to a maximum of 1 (one) year imprisonment and/or a maximum fine of Rp100. 000,000 (one hundred million rupiah). Clause 24 paragraph (2) letter c, which regulates the economic rights of a Phonogram Producer which includes the right to carry out, give permission, or prohibit other parties from making public leases of phonogram copies. The violation of this clause is according to clause 78 of the Indonesian Criminal Code after 6 years;

2. Any person who intentionally and without right violates economic rights as referred to in clause 24 paragraph (2) letter $\mathrm{a}$, letter $\mathrm{b}$, and/or letter $\mathrm{d}$ for Commercial Use, shall be liable to a maximum imprisonment of 4 (four) year and/or criminal fine of no more than Rp1,000,000,000.00 (one billion). Clause 24 paragraph (2) letter a, letter $b$, and letter $d$, regulates the economic rights of a Phonogram Producer which includes the right to carry out, give permission, or prohibit other parties from making a phonogram copy in any way or form, distributing the original phonogram or a copy, and make provision for phonograms with or without cables that are publicly accessible. The violation of this clause is according to clause 78 of the Indonesian Criminal Code after 12 years.

g. Clause 118:

1. Any person who intentionally and without the right violates the economic rights as referred to in Clause 25 paragraph (2) letter $\mathrm{a}$, letter $\mathrm{b}$, letter $\mathrm{c}$, and/or letter $\mathrm{d}$ for Commercial Use, shall be liable to a maximum imprisonment of 4 (four) years and / or criminal penalties with a maximum of Rp1,000,000,000.00 (one billion rupiah). Clause 25 paragraph (2) letter a, letter b, letter $\mathrm{c}$, and letter $\mathrm{d}$ regulate the economic rights of broadcasting institutions which include the right to exercise alone, give permission, or prohibit other parties from re-broadcasting, broadcast communication, broadcast fixation, and/or doubling of broadcast fixation. The violation of this clause is according to clause 78 of the Indonesian Criminal Code after 12 years. 
Adhi Budi Susilo and Jarot Jati Bagus S, Renewal of Criminal...

2. Every person who fulfills the elements referred to in Clause 25 paragraph (2) letter d committed with the intention of hijacking shall be sentenced to a maximum imprisonment of 10 (ten) years and/or a maximum fine of Rp.4,000,000,000.00 (four billion rupiah). The violation of this clause is according to clause 78 of the Indonesian Criminal Code after 12 years.

h. Clause 119:

Every Collective Management Institution that does not have an operational permit from the Minister as referred to in Clause 88 paragraph (3) and conducts Royalty withdrawal shall be punished with a maximum imprisonment of 4 (four) years and/or a maximum fine of Rp1,000,000,000.00 (one billion). The violation of this clause is according to clause 78 of the Indonesian Criminal Code after 12 years. Clause 95 paragraph (4) of Law Number 28 Year 2014 states that in addition to infringing Copyright and/or Related Rights in the form of Piracy, as long as the parties to the dispute are known to exist and/or are in the territory of the Unitary State of the Republic of Indonesia must first settle dispute through mediation before making criminal charges. Reporting to the Officials of the Republic of Indonesia National Police or Civil Servants regarding copyright infringement can be done after the temporary determination of the commercial court is established (Clause 109 paragraph (4) letter c of Law Number 28 of 2014 concerning Copyright)

The regulation of copyright infringement as a complaint offense in terms of legal protection of the rights of the creator or the copyright holder is seen as unfairly accommodating the rights of the creator and the copyright holder in Indonesia. In its development, Indonesia is a participating country that has ratified WTO trade provisions that have adopted TRIPs as a source of law in which there is a provision that intellectual property rights are private rights. This private right statement becomes relevant to the criminal code, namely offense for complaint. In terms of economics, changing the offense of copyright regulation to an offense of complaint gives victims a choice, this largely results in copyright infringement for creators in this 
country who do not fully understand the concept of modern copyright which contains capitalist and liberal values. Therefore, it is necessary to have a renewal of criminal law which no longer protects capitalist rights but also among creators who do not understand the principles of modern copyright. In line with this, Sri Endah states that: (Wahyuningsih, 2013: 68)

If what is aspired by national law is the Pancasila legal system, then it is fitting to study and develop criminal law that contains Pancasila values, meaning that criminal law is oriented to the Godhead value of God Almighty, criminal law oriented to the value of Just and Civilized Humanity, criminal law which is based on the value of Unity, and criminal law which is imbued with the values of Society Led by Wisdom Wisdom in Consultation/Representation and the value of Social Justice for All Indonesian People.

In connection with the views of Sri Endah above, Notonagoro stated that: (Wahyuningsih, 2013: 69)

The benchmark of the practical philosophy of Indonesian national law is Pancasila, which is an abstraction of the noble values of Indonesian society which contains the ideals of the nation, which are just and prosperous society both materially and spiritually, and the life of the Indonesian people as a whole.

Furthermore in line with the various views above as well, Barda Nawawi states that: (Arief, 1996: 41)

That criminal law reform is in essence an effort to reorient and reevaluate the socio-political, socio-philosophical, socio-cultural values which underlie and provide content to the normative and substantive contents of the criminal law aspired.

Based on the various views above, it is clear that the shift from offense to copyright to complaint offense is very far from the spirit of protection for the creator of a work that will ultimately result in injustice of the law, in order to bring about justice in the field of offense related to copyright, the politics of criminal law related to offense copyright should no longer be a complaint offense as the western concept but it should be a special offense that can automatically be imposed on copyright authors without the need to wait for 
a complaint from the copyright owner to be able to realize the value of social justice for all Indonesian people in the copyright sector.

\section{Clonclusion}

Based on the various explanations above it is clear that the need for political reform of criminal law related to copyright offenses that better protect the creators of a work of copyright by changing the complaint offense on copyright offense into a special offense that can be acted on without needing to wait for complaints from the creator who created harmed. [w]

\section{Reference}

Academic Manuscript Draft Law on Copyright, 2013.

Arief, Barda Nawawi. 1996. Interest in Criminal Law Policy, Bandung: Citra Aditya Bakti.

Constitution 19 Year 2002 Regarding Copyright

Constitution 28 Year 2014 Regarding Copyright

Criminal Law Code

Gunaidi, Ismu and Efendi, Jonaedi. 2014. Quick and Easy to Understand Criminal Law. Jakarta: Kencana Prenadamedia Group.

Haryanto, Ignatyus. 2014. Heretical Thinking of Intellectual Property. Jakarta: Gramedia's Popular Literature.

Hiariej, Eddy O.S. 2014. Principles of Criminal Law. Yogyakarta: Cahaya Atma Pustaka.

Jamba, Padrisan. 1963. "Analysis of the Implementation of the Delict of Complaints in the Copyright Act to Tackle Copyright Crimes in Indonesia”, Jurnal Cahaya Keadilan. 1 (3): 2339

Mashdurohatun, Anis. 2012. "Problems of Copyright Protection in Indonesia", Yustisia Journal of Law 1 (1). 
Minutes of Special Committee on Copyright Bill Draft Meeting, 1st Special Committee Meeting, 21 May 2014,

Miryansyah. 2016. "A legal analysis of copyright criminal acts (based on law number 28 of 2014 concerning copyright"

Mittelstaedt, Jhon D and Mittelstaedt, Robert A. 1997. "The Protection of intellectual Property: Issues of Orgination and Ownership", Journal of Public Policy and Marketing 1 (16)

Purba, Achmad Zen Umar. tt. Agreement and Some Strategic Issues, Bandung: Alumni.

Raharjo, Satjipto. 2000. Ilmu Hukum. Bandung: PT. Citra Aditya Bakti.

Raharjo, Trisno. 2006. Legislative Policy in the Regulation of Intellectual Property Rights with Penal Facilities. Yogyakarta: Law Office of Trisno Raharjo.

Ramadhan, Dhimas Putra. 2017. A Legislative Policy on Amendments to Regulations on Copyright Infringement as a Delict of Complaints to Law Number 28 of 2014 Judging from the Protection of the Rights of Creators or Copyright Holders. Thesis. Yogyakarta: Indonesian Islamic University.

Results of a Working Visit on the Draft Copyright Law in the Province of East Kalimantan, May 15-17, 2014.

Saidin, OK. 2015. Legal Aspects of Intellectual Property Rights. Jakarta: PT. Raja Grafindo Persada.

Salim and Nurbani, Erlies Septiana. 2013. Application of Legal Theory in Thesis and Dissertation Research. Jakarta: PT. Raja Grafindo Persada.

Susilo, AB. 2018. Pocket Book for Classifying Intellectual Property Rights. Semarang: LPPM Unnes.

The 1945 Constitution of the Republic of Indonesia

Wahyuningsih, Sri Endah. 2013. Principles of Criminal Individualization in Islamic Criminal Law and Renewal of Indonesian Criminal Law. Semarang: Undip.

Warasih, Esmi. 2014. Legal Institution: A Sociological Review. Semarang: Reader Literature. 
Adhi Budi Susilo and Jarot Jati Bagus S, Renewal of Criminal...

Wibowo, Ari. 2015. "Justification of Criminal Law against Criminalization Policy of Copyright Infringement, as well as Formulation of Juridical Qualifications and Types of Delicts Legal", Journal IUS QUIA Iustum 1 (22). 